\title{
Readiness of PSMZA Lecturer on The Use of Mooc Platform in Learning and Teaching
}

\author{
Hasliza Binti Hashim ${ }^{1 *}$, Pazlina Binti Mat $\mathrm{Ali}^{2}$ \\ ${ }^{12}$ Politeknik Sultan Mizan Zainal Abidin \\ Đe-mail: hasliza@psmza.edu.my
}

\begin{abstract}
Currently, Malaysia is faced with challenges in efforts to provide a quality educational system. One of the surge in the Development Plan of Education (higher education) 2015-2025 is to ensure learning online at global level. So with this, the use of platform MOOC is one the first method was introduced as one of the approaches in learning and teaching. However the question arises whether polytechnic lecturer was ready to use online learning extensively, particularly in the process of learning and teaching. This study is intended to review the availability of committed lecturers Politeknik Sultan Mizan Zainal Abidin of the use of platform MOOC in learning and teaching. Respondents were 153 lecturers in PSMZA and it has been selected at random. The instruments used are a set of survey questions. The findings indicate the availability of lecturers PSMZA will against the use of platform MOOC in learning and teaching are not influenced by gender. The mean score for female lecturers was 2.83 compared mean score men namely 2.57 and this shows women more ready against the use of platform MOOC. The mean score for aspects of female lecturers obstacles higher than male lecturers. This suggests that female lecturers more willing to use MOOC in learning and teaching although there are some aspects which have become obstacles. Someone who had the expectation of high availability using MOOC are less face obstacles while using MOOC in learning and teaching sessions. Coefficient of correlation variables obstacles in the use of MOOC and graduate readiness against MOOC is very weak with the value of the coefficient of correlation of -0.078. It is mean that female lecturers more willing to use MOOC in learning and teaching although there are some aspects which have become obstacles. Therefore clearly showed the use of MOOC among the lecturers PSMZA will provide positive indicators and should be polished to ensure the integration of technology in education achieved towards helping towards the Industrial Revolution 4.0.
\end{abstract}

Keywords:MOOC; availability; lecturers.

\section{Kesediaan Pensyarah Psmza terhadap Penggunaan Platform Mooc dalam Pembelajaran dan Pengajaran}

\begin{abstract}
Pada masa ini, Malaysia menghadapi cabaran dalam usaha menyediakan sistem pendidikan berkualiti. Salah satu daripada peningkatan dalam Rancangan Pembangunan Pendidikan (pendidikan tinggi) 2015-2025 adalah untuk memastikan pembelajaran dalam talian di peringkat global. Jadi dengan ini, penggunaan platform MOOC adalah satu kaedah pertama diperkenalkan sebagai salah satu pendekatan dalam pembelajaran dan pengajaran. Walau bagaimanapun persoalannya timbul sama ada pensyarah politeknik sudah bersedia untuk menggunakan
\end{abstract}


pembelajaran dalam talian secara meluas, terutamanya dalam proses pembelajaran dan pengajaran. Kajian ini bertujuan untuk mengkaji semula ketersediaan pensyarah yang berpengalaman Politeknik Sultan Mizan Zainal Abidin dari penggunaan platform MOOC dalam pembelajaran dan pengajaran. Responden adalah 153 pensyarah di PSMZA dan telah dipilih secara rawak. Instrumen yang digunakan adalah satu set soalan tinjauan. Penemuan menunjukkan adanya pensyarah PSMZA terhadap penggunaan MOOC platform dalam pembelajaran dan pengajaran tidak dipengaruhi oleh jantina. Skor min bagi pensyarah perempuan ialah 2.83 berbanding lelaki purata min iaitu 2.57 dan ini menunjukkan wanita lebih bersedia menentang penggunaan MOOC platform. Skor min bagi aspek pensyarah perempuan yang lebih tinggi daripada pensyarah lelaki. Ini menunjukkan bahawa pensyarah wanita lebih sanggup menggunakan MOOC dalam pembelajaran dan pengajaran walaupun terdapat beberapa aspek yang telah menjadi halangan. Seseorang yang mempunyai jangkaan keupayaan tinggi menggunakan MOOC kurang menghadapi masalah semasa menggunakan MOOC dalam sesi pembelajaran dan pengajaran. Kaedah pemboleh ubah rintangan korelasi dalam penggunaan MOOC dan kesediaan siswazah terhadap MOOC sangat lemah dengan nilai koefisien korelasi 0.078. Ini bermakna bahawa pensyarah wanita lebih bersedia menggunakan MOOC dalam pembelajaran dan pengajaran walaupun terdapat beberapa aspek yang menjadi halangan. Oleh itu dengan jelas menunjukkan penggunaan MOOC di kalangan pensyarah PSMZA akan memberikan penunjuk positif dan harus digilap untuk memastikan integrasi teknologi dalam pendidikan yang dicapai ke arah membantu menuju Revolusi Industri 4.0.

Keywords:MOOC; ketersediaan; pensyarah.

\section{PENGENALAN}

Pendidikan di Malaysia pada abad ini semakin menunjukkan satu perubahan yang positif dan kehadapan dengan adanya perkembangan dalam penggunaan teknologi. Perubahan ini seterusnya dapat meningkatkan kadar pencapaian dengan lebih efektif. Penggunaan alat bantu mengajar dan juga kepelbagaian kaedah pengajaran secara tradisional sedikit sebanyak mempengaruhi pencapaian pelajarpelajar. Dengan adanya perkembangan teknologi dalam bidang pendidikan, pelajar- pelajar tidak perlu bergantung kepada buku sahaja semasa di dalam kelas. Kaedah pembelajaran melalui aplikasi teori-teori pembelajaran yang bersesuaian dengan perkembangan teknologi telah menyumbang kepada perubahan dan penambahbaikan (Jailani, 2015). Perkembangan ini turut memberi implikasi terhadap kaedah pembelajaran seperti Pembelajaran Teradun (blended learning) atau pembelajaran berbalik (flipped learning) yang dapat dicapai melalui penggunaan landasan pembelajaran seperti Sistem Pengurusan Pembelajaran (Learning Management System - LMS) serta pelantar kursus dalam talian secara terbuka iaitu Massive Open Online Course (MOOC). Kementerian Pendidikan Tinggi Malaysia telah mengambil inisiatif selaras bagi memenuhi aspirasi Pelan Pembangunan Pendidikan Malaysia (Pendidikan Tinggi) 2015-2025 yang mengandungi 10 lonjakan di mana diharapkan pelan ini dapat melonjakkan penggunaan teknologi dalam mengejar status negara maju seiring dengan negara-negara besar di peringkat global. Tujuan pelan pembangunan ini diadakan adalah untuk memastikan akses pendidikan diperluaskan, kualiti pembelajaran dan pengajaran dipertingkatkan, kos penyampaian dapat dikurangkan dan seterusnya IPT Malaysia dapat ditonjolkan di arena antarabangsa di samping memupuk pembelajaran sepanjang hayat khususnya dalam kalangan warga Malaysia.

Bagi memenuhi aspirasi ini, kursus MOOC di Malaysia telah dibangunkan pada sekitar tahun 2014 oleh setiap bahagian e-pembelajaran universiti awam hasil cadangan daripada pihak Kementerian Pendidikan Malaysia. Menurut Ketua Pengarah Pendidikan Tinggi, Prof. Dr. Asma Ismail, golongan celik komputer di negara ini bakal menempuhi satu pengalaman baharu dalam sistem pendidikan yang menggunakan MOOC (Utusan Online, 2016). Pembelajaran menggunakan MOOC dikatakan kaedah pembelajaran yang terbaru kerana MOOC ini sendiri menekankan beberapa aspek seperti ciri-ciri fizikal pembangunan MOOC, kaedah dan cara penyampaian maklumat kepada pengguna dan juga bahan-bahan kursus yang dikongsi antara pelatih kursus dengan pelajarnya. 
Sehubungan itu, bagi memastikan pembelajaran dalam talian berada pada tahap global, politeknik telah mengambil inisiatif untuk membudayakan penggunaan MOOC ini di kalangan warga politeknik. Menurut Y.bhg. Prof. Dato' Dr. Mohd Ismail Bin Abd Aziz, Ketua Pengarah Jabatan Pendidikan Politeknik dan Kolej Komuniti Kementerian Pendidikan Tinggi dalam Amanat Ketua Pengarah Tahun Baru 2018 menyatakan bahawa 35 MOOC telah dilaksanakan pada tahun 2017 berbanding 19 MOOC pada tahun 2016. Penggunaan MOOC juga telah membantu peningkatan pengambilan pelajar sebanyak 2.72 peratus kepada 35,744 pelajar pada tahun 2017. Pada masa ini, 13.85 peratus pelajar menggunakan MOOC Politeknik yang melibatkan 53 kursus. Pihak kementerian juga telah menyasarkan 40 peratus pelajar politeknik menggunakan MOOC melalui penawaran 70 kursus mulai tahun 2018. (Ismail, 2018)

\section{Pernyataan Masalah}

Salah satu daripada Pelan Pembangunan Pendidikan Malaysia (Pendidikan Tinggi), iaitu lonjakan kesembilan, ada menyatakan bahawa matlamatnya adalah untuk memastikan pembelajaran dalam talian berada pada tahap global. Sehubungan dengan ini, Kementerian Pendidikan Tinggi menggunakan MOOC sebagai satu keutamaan bagi dalam memastikan objektif pelan ini tercapai. Sehubungan dengan itu, para pendidik perlu sentiasa bersedia untuk melakukan anjakan paradigma dalam sistem pendidikan. Ini penting bagi memastikan agenda pendidikan negara kita untuk membina sebuah negara bangsa yang maju dan bersatu-padu dapat dicapai sebagaimana yang dihasratkan. Dalam konteks ini, pensyarah - pensyarah di politeknik harus memainkan peranan penting agar dapat mendidik pelajar dengan pembelajaran atas talian. Namun timbul persoalan sama ada pensyarah politeknik telah bersedia untuk menggunakan pembelajaran dalam talian secara meluas terutamanya dalam proses pembelajaran dan pengajaran. Oleh itu, kajian ini dilakukan bertujuan untuk mengkaji kesediaan pensyarah Politeknik Sultan Mizan Zainal Abidin terhadap penggunaan platform MOOC dalam pembelajaran dan pengajaran.

\section{Objektif Kajian}

i. Mengkaji kesediaan pensyarah PSMZA menggunakan platform MOOC dalam pengajaran danpembelajaran.

ii. Mengenalpasti hubungan antara halangan dan kesediaan pensyarah menggunakan platform MOOC dalampembelajaran.

\section{LITERATUR REVIEW}

\section{Massive Open Online Course (MOOC)}

Massive Open Online Course atau singkatannya dipanggil MOOC terkenal sebagai satu kaedah pembelajaran terkini di seluruh dunia (McGuire, 2014). Namun secara dasarnya kursus MOOC di Malaysia dibangunkan pada sekitar tahun 2014 oleh setiap bahagian e-pembelajaran universiti awam hasil cadangan daripada pihak Kementerian Pendidikan Malaysia. MOOC Malaysia boleh dibahagikan kepada 3 jenis kursus seperti kursus umum, kursus tujahan (niche) dan kursus pembelajaran sepanjang hayat (Hudiya, Fariza, \& Aidah, 2017). Secara keseluruhannya, pembangunan MOOC hampir sama dengan pembelajaran atas talian yang lain cuma yang membezakannya adalah ciri-ciri keterbukaan yang terhad kepada pendaftaran atau keterlibatan bukan dari sudut perkongsian maklumat bahan. MOOC digunakan secara meluas kerana ianya percuma tanpa bayaran. Dengan ini, menjadikan MOOC salah satu peluang untuk meneroka pengetahuan dengan lebih meluas. MOOC banyak memberi kesan kepada pendidikan terutama proses pembelajaran dan pengajaran. Ahshehri (2015) menyokong kenyataan tersebut dengan menyatakan MOOC dapat memberi kesan positif dalam proses pendidikan.

Tujuan utama pelajar mengikuti kursus atas talian ini adalah bagi memenuhi keperluan semasa pengajian, menerima arahan daripada pensyarah kursus, mempunyai sifat ingin tahu dan mencuba sesuatu yang baharu serta dapat berinteraksi dengan masyarakat (Zheng et. al. 2015) .Cadangan yang dapat diajukan adalah menyebarkan dan meluaskan kaedah penggunaan MOOC di setiap institusi di Malaysia. Di samping menggalakkan ramai lagi pengkaji meneliti kajian MOOC di Malaysia (Hudiya Adzhar, Fariza Khalid, 2015). Pelbagai kajian telah dibuat dalam pembelajaran atas talian ini. Kajian daripada Jailani (2015) mendapati bahawa tahap komunikasi yang berubah lebih positif memainkan peranan dalam mempengaruhi mereka untuk terus menggunakan e-learning. Selain daripada berkomunikasi dengan lebih 
ramai individu, e-learning juga membantu meningkatkan keupayaan diri responden dalam menyuarakan pandangan atau idea. Ia juga membantu meningkatkan keyakinan diri pelajar dalam memberikan pandangan terhadap pendapat individu yang lain. Seterusnya, secara tidak langsung, e-learning telah membantu pelajar meningkatkan kebolehan diri dalam berkomunikasi secara keseluruhannya. Ini bertepatan dengan kajian daripada Mohammed Omer et al. (2015) menyatakan pelajar mempunyai sikap yang sangat positif terhadap e-pembelajaran, dan mereka dilihat bahawa e-pembelajaran meningkatkan pengalaman pendidikan mereka. Kajian daripada Cole \& Ph (2015) pula menyatakan bahawa dalam aspek pembelajaran, seorang pelajar menyatakan bahawa walaupun MOOC mungkin sumber yang boleh dipercayai untuk kandungan, ia tidak semestinya sesuai bagi sumber pembelajaran dan pengajaran. Ini menunjukkan bahawa terdapat banyak kajian terdahulu yang dibuat adalah berdasarkan pada perspektif pelajar itu sendiri dan bukannya kepada pendidik.

\section{Kesediaan}

Guru memainkan peranan utama dalam menentukan kualiti implementasi mana-mana polisi pendidikan yang baharu (Fullan,1993). Menurut Wearmouth, Edwards \& Richmond (2000) dalam Nor Azlina (2015), menyatakan bahawa perubahan dalam pendidikan telah gagal disebabkan kurangnya perhatian diberikan kepada aspek pelaksanaan, khususnya keperluan para pelaksana. Oleh yang demikian, usaha untuk menyelidiki kesediaan para guru dalam mengimplementasi mana-mana program pendidikan yang baharu perlu dilakukan kerana ia boleh menentukan kejayaan sesuatu program baharu itu. Menurut kajian yang dijalankan oleh Nor (2012), proses pembelajaran dan pengajaran dapat dipertingkatkan sekiranya seseorang pendidik itu mempunyai kesediaan terhadap sesuatu matapelajaran yang akan diajar. Di samping itu juga pendidik akan lebih berasa yakin semasa menjalankan tugasnya seharian. Dalam kajian yang dijalankan oleh Sihes \& Bandi (2010) menunjukkan bahawa bakal-bakal guru mempunyai kesediaan yang tinggi untuk mengajar terutamanya apabila dikaji dari aspek pengetahuan, tahap kemahiran, tahap pendedahan dan sikap bakal-bakal guru dalam melaksanakan proses pembelajaran dan pengajaran. Ini berlainan dari kajian yang dijalankan oleh Rase (2013) terutamanya dalam menggunakan pendekatan $\mathrm{m}$ - learning, di mana kesediaan pensyarah dari aspek pengetahuan adalah rendah, tetapi kesediaan adalah tinggi dari aspek sikap dan seterusnya aspek kemahiran adalah pada tahap sederhana. Hasil dapatan kajian tersebut adalah bagi melihat hubungan yang sangat kuat dan signifikan bagi ketigatiga aspek kesediaan pensyarah. Aspek kesediaan ini perlu diberi perhatian oleh pensyarah dalam memastikan bahawa lonjakan yang terdapat di dalam Pelan Pembangunan Pendidikan Malaysia (Pendidikan Tinggi) 2015-2025 dalam memastikan pembelajaran dalam talian pada tahap global tercapai.

Aspek kesediaan merupakan satu faktor yang penting bagi seseorang pendidik dalam menyampaikan pengajarannya. Secara amnya, keupayaan seseorang pendidik dalam menyampaikan ilmu pengetahuan juga sering dikaitkan dengan kejayaan atau kegagalan seseorang pelajar. Walaupun guru dianggap sebagai pemacu ke arah kejayaan kaedah pembelajaran ini, namun masih terdapat bilangan guru yang belum menguasai teknologi komputer dan masih lagi tidak bersedia untuk mengaplikasikannya (Peter, 2007). Kajian yang dijalankan oleh Attan \& Mohd Hamzah (2007), kesediaan guru merupakan elemen penting dan memainkan peranan dalam membantu pelajar menyesuaikan diri dalam suasana dan kaedah pembelajaran baru serta didedahkan dengan penggunaan teknologi baru. Sekiranya guru tidak bersedia, maka segala program yang akan dijalankan oleh pihak kementerian tidak akan dicapai. Oleh itu, kajian ini diharap dapat memberi gambaran jelas khususnya kepada pensyarah untuk melihat sejauh mana kesediaan yang perlu ada pada diri mereka dalam menggunakan platform MOOC di politeknik.

\section{METODOLOGI}

Suatu kaedah dan teknik tertentu untuk memperolehi maklumat yang diperlukan dalam sesebuah kajian digelar reka bentuk kajian. Reka bentuk kajian merupakan sebuah panduan bagi mendapatkan jawapan yang jelas terhadap persoalan kajian yang dilakukan di awal perancangan kajian (Kerlinger, 1973). Satu kajian tinjauan deskriptif akan digunakan dalam pelaksanaan kajian ini dengan menggunakan instrumen soal selidik. Soalan soal selidik ini dibahagikan kepada 3 bahagian iaitu Bahagian A (demografi responden), Bahagian B (aspek kesediaan) dan Bahagian C (aspek halangan).Jenis kajian 
yang digunakan adalah jenis deskriptif. Proses yang dijalankan dalam kajian jenis deskriptif adalah mengenal pasti komponen kajian dan keterangan kaitan antara komponen (Mohd.Najib,2003). Menurut Mohd.Majid (2000), "Penyelidikan deskriptif merupakan penyelidikan yang bermatlamat untuk menerangkan sesuatu fenomena yang sedang berlaku" (p.96). Seterusnya, maklumat tersebut diproses mengikut kaedah analisis yang dirancang oleh pengkaji. Kaedah ini dilaksanakan bagi mendapatkan data dari sampel bersaiz besar (Mohd Najib, 2013). Kaedah tinjauan dalam kajian pendidikan deskriptif melibatkan aktiviti pengumpulan maklumat daripada pensyarah-pensyarah Politeknik Sultan Mizan Zainal Abidin (PSMZA) yang terlibat dalam sistem pendidikan. Sampel yang dipilih adalah seramai 153 orang pensyarah dan diambil secara rawak (Cohen, 2011). Instrumen yang digunakan dalam kajian ini adalah soal selidik. Data primer bagi kajian ini diperoleh melalui pengedaran borang soal selidik kepada responden yang melibatkan para pensyarah di Politeknik Sultan Mizan Zainal Abidin sebagai sampel kajian manakala data sekunder pula diperolehi daripada jurnal-jurnal dan laporan yang dikeluarkan oleh Kementerian Pendidikan Tinggi. Segala maklumat yang diperolehi dianalisis dengan menggunakan perisian Statistical Package for Social Sciene (SPSS) versi 23.0 bagi mengetahui tahap kesediaan pensyarah terhadap penggunaan platform MOOC dalam pembelajaran dan pengajaran.

\section{Kebolehpercayaan}

Menurut Konting (2005), kebolehpercayaan adalah suatu alat pengukuran yang boleh ditentukan dengan menggunakan indeks kepercayaan. Dalam kajian ini, pekali alpha cronbach dikenalpasti untuk mengukur ketekalan dalaman item dalam soal selidik. Ujian alpha cronbach dijalankan bagi menentukan ketekalan dalaman dan kaedah ini mengandaikan bahawa setiap item dianggap satu ujian yang setara dengan semua kolerasi antara item yang diukur adalah sama. Berdasarkan Jadual 1 iaitu intreprestasi skor $\alpha$ berdasarkan Bond dan Fox (2007), nilai kebolehpercayaan yang kurang daripada 0.60 adalah dianggap rendah dan tidak boleh diterima, nilai $\alpha$ antara 0.60 hingga 0.80 adalah diterima manakal nilai $\alpha$ yang melebihi 0.80 adalah dianggap baik.

\section{Jadual 1}

Intreprestasi Skor ( $\alpha$ ) Berdasarkan Bond Dan Fox (2007)

\begin{tabular}{|c|l|}
\hline $\begin{array}{c}\text { Skor alpha cronbach }( \\
\boldsymbol{\alpha})\end{array}$ & \multicolumn{1}{c|}{ Kebolehpercayaan } \\
\hline $0.9-1.0$ & Sangat baik dan efektif dengan tahap konsisten yang tinggi \\
\hline $0.7-0.8$ & Baik dan boleh diterima \\
\hline $0.6-0.7$ & Boleh diterima \\
\hline$<0.6$ & Item perlu diperbaiki \\
\hline$<0.5$ & Item perlu digugurkan \\
\hline
\end{tabular}

\section{Kajian Rintis}

Bagi memantapkan lagi kesahan soal selidik yang akan diguna pakai, satu kajian rintis akan dilakukan. Kajian ini telah diedarkan kepada pensyarah - pensyarah PSMZA secara rawak. Melalui kajian rintis pengkaji dapat menilai tahap pemahaman tentang instrumen yang dibina. Hasil daripada kajian rintis juga dianalisis menggunakan kaedah yang sama seperti kajian sebenar iaitu menggunakan Statistical Packages For Social Sciences 23.0 (SPSS) selepas melalui ujian alpha cronbach. Jadual 2 menunjukkan hasil daripada analisis kebolehpercayaan item - item di dalam borang soal selidik. Hasil analisis kebolehpercayaan menunjukkan tahap kebolehpercayaan yang tinggi dengan nilai 0.912 pada bahagian A dan 0.753 untuk bahagian B. Mengikut interpretasi daripada Bond and Fox (2007), nilai yang diperolehi adalah sangat baik dan efektif dengan tahap konsisten yang tinggi.

Jadual 2

Analisis Kebolehpercayaan

Kebolehpercayaan Statistik

\begin{tabular}{l|l|l|r} 
Bahagian & Pekali Alpha & Jumlah Item & Interpretasi
\end{tabular}




\begin{tabular}{|l|c|c|c|l|}
\hline $\begin{array}{l}\text { Bahagian B } \\
\text { Kesediaan }\end{array}$ & 0.912 & 12 & $\begin{array}{l}\text { Sangat baik dan efektif dengan } \\
\text { tahap konsisten yang tinggi }\end{array}$ \\
\hline $\begin{array}{l}\text { Bahagian C } \\
\text { Halangan }\end{array}$ & : Aspek & 0.753 & 8 & Baik dan boleh diterima \\
\hline
\end{tabular}

Untuk menganalisis bahagian $\mathrm{B}$ dan $\mathrm{C}$, pengkaji menggunakan ujian $\mathrm{t}$ bagi melihat perbezaan kesediaan pensyarah terhadap jantina manakala ujian korelasi Pearson pula digunakan untuk menentukan terdapat hubungan yang signifikan atau tidak di antara aspek kesediaan dan halangan bagi pensyarah.

\section{DAPATAN KAJIAN DAN PERBINCANGAN}

Analisis keseluruhan domain ini adalah untuk mengetahui kesediaan pensyarah psmza terhadap penggunaan platform mooc di bandingkan dengan jantina. Melalui analisis yang dibuat, didapati skor min bagi aspek kesediaan adalah sebanyak 2.69 dan bagi aspek halangan pula, skor min adalah 2.90 (jadual 3). Kedua - dua nilai ini adalah di tahap sederhana. Bagi melihat tahap amalan ini, pengkaji telah merujuk kepada jadual interpretasi skor min empat skala seperti di jadual 4

Jadual 3

Jadual interpretasi skor min kesediaan dan halangan

\begin{tabular}{cccc}
\hline Bahagian & Aspek & Min & Interpretasi \\
\hline Bahagian b & Kesediaan & 2.69 & Sederhana \\
Bahagian c & Halangan & 2.90 & Sederhana \\
\hline
\end{tabular}

Jadual 4

Jadual interpretasi skor min empat skala

\begin{tabular}{|c|c|}
\hline Selang skala min & Interpretasi tahap \\
\hline $1.00-2.00$ & Rendah \\
\hline $2.01-3.00$ & Sederhana \\
\hline $3.01-4.00$ & Tinggi \\
\hline & Sumber: ghani hj taib (1996)
\end{tabular}

Kesediaan pensyarah psmza menggunakan platform mooc dalam pembelajaran dan pengajaran.

Kesediaan pensyarah psmza menggunakan platform mooc dalam pembelajaran dan pengajaran mengikut jantina

Merujuk kepada jadual 5, tidak terdapat perbezaan yang signifikan min skor kesediaan di antara jantina di kalangan pensyarah di politeknik sultan mizan zainal abidin. Pengkaji mendapati pensyarah perempuan mempunyai nilai tahap skor min pada tahap yang sederhana.

Jadual 5

Perbezaan kesediaan pensyarah mengikut jantina

\begin{tabular}{cccccc}
\hline Jantina & $\mathrm{N}$ & $\mathrm{Min}$ & $\mathrm{Sd}$ & $\mathrm{T}$ & $\mathrm{P}$ \\
\hline Lelaki & 83 & 2.5673 & 0.6895 & -2.917 & 0.004 \\
Perempuan & 70 & 2.8262 & 0.3880 & & \\
\hline
\end{tabular}




\section{Halangan pensyarah psmza menggunakan platform mooc dalam pembelajaran danpengajaran}

Daripada analisis ujian t yang dibuat juga, didapati terdapat perbezaan yang signifikan min skor halangan di antara jantina di kalangan pensyarah di politeknik sultan mizan zainal abidin. Ini menunjukkan pensyarah perempuan lebih banyak mempunyai halangan dalam penggunaan platform mooc ini. Data adalah seperti ditunjukkan dalam jadual 6.

Jadual 6

Perbezaan halangan pensyarah mengikut jantina

\begin{tabular}{cccccc}
\hline Jantina & $\mathrm{N}$ & $\mathrm{Min}$ & $\mathrm{Sd}$ & $\mathrm{T}$ & $\mathrm{P}$ \\
\hline Lelaki & 83 & 2.8524 & 0.36944 & 0.209 & 0.110 \\
Perempuan & 70 & 2.9236 & 0.40779 & & \\
\hline
\end{tabular}

Berdasarkan analisa yang dijalankan, pengkaji mendapati bahawa kesediaan pensyarah psmza terhadap penggunaan platform mooc dalam pembelajaran dan pengajaran tidak dipengaruhi oleh jantina. Min bagi pensyarah wanita ialah 2.83 menunjukkan mereka lebih bersedia terhadap penggunaan platform mooc. Namun begitu, hasil analisa juga mendapati bahawa terdapat halangan dalam menggunakan platform mooc di kalangan pensyarah mengikut jantina. Min bagi aspek halangan pensyarah wanita lebih tinggi berbanding pensyarah lelaki. Ini menunjukkan bahawa pensyarah wanita lebih bersedia untuk menggunakan mooc dalam pembelajaran dan pengajaran walaupun terdapat beberapa aspek yang menjadi halangan.

\section{Mengenalpasti hubungan antara halangan dan kesediaan pensyarah terhadap penggunaan platform mooc dalam pembelajaran dan pengajaran}

Halangan didefinisikan sebagai rintangan yang dihadapi oleh pelajar yang akan membawa kesan yang negatif terhadap mereka semasa menggunakan platform mooc. Halangan dalam pembelajaran boleh membawa kepada kesan terhadap seseorang pelajar dalam pembelajaran. Jadual 7 menunjukkan terdapat 7 item mengenai halangan-halangan yang dihadapi oleh pensyarah psmza dalam menggunakan platform mooc untuk tujuan pembelajaran dan pengajaran.

Jadual 7 : halangan pensyarah psmza menggunakan mooc dalam pdp

\begin{tabular}{clccc}
\hline Item & \multicolumn{1}{c}{ Pernyataan } & Min & Sisihan piawai & Interpretasi \\
\hline 1 & Sumber liputan internet/wifi yang rendah & 2.95 & 0.97 & Sederhana \\
\hline 2 & Kurang kefahaman dalam menggunakan mooc & 3.01 & 0.78 & Tinggi \\
\hline 3 & $\begin{array}{l}\text { Peralatan untuk menggunakan mooc tidak } \\
\text { lengkap }\end{array}$ & 2.79 & 0.83 & Sederhana \\
\hline 4 & $\begin{array}{l}\text { Tidak dapat memberi komitmen sepenuhnya di } \\
\text { atas talian }\end{array}$ & 3.22 & 0.64 & Tinggi \\
\hline 5 & $\begin{array}{l}\text { Tiada motivasi diri untuk menyertai pdp dalam } \\
\text { mooc }\end{array}$ & 2.93 & 0.79 & Sederhana \\
\hline 6 & $\begin{array}{l}\text { Bahan dalam kursus mooc tidak menarik } \\
\text { /membosankan }\end{array}$ & 2.44 & 0.84 & Sederhana \\
\hline 7 & $\begin{array}{l}\text { Tidak semua kursus ada ditawarkan dalam } \\
\text { mooc }\end{array}$ & 2.82 & 0.73 & Sederhana \\
\hline 8 & $\begin{array}{l}\text { Tidak mempunyai masa yang mencukupi untuk } \\
\text { menyediakan platform mooc }\end{array}$ & 3.04 & 0.78 & Tinggi \\
\hline
\end{tabular}

Item yang mencatat min yang tertinggi adalah item 2 iaitu sebanyak 3.22. Item ini adalah mengenai "tidak dapat memberi komitmen sepenuhnya di atas talian". Ini adalah halangan tertinggi kepada pensyarah untuk menggunakan mooc dalam pembelajaran dan pengajaran. Item yang mencatat min yang paling kurang adalah item 6 yang menyatakan bahawa "bahan dalam kursus mooc tidak menarik /membosankan”. Ini bermakna item tersebut bukan merupakan halangan utama bagi pensyarah dalam 
menggunakan platform mooc. Secara keseluruhan, halangan-halangan penggunaan mooc berada di tahap halangan yang sederhana. Purata min secara keseluruhan adalah 2.90. Ini menunjukkan halanganhalangan masih wujud dan langkah-langkah perlu diambil untuk mengatasi halangan-halangan tersebut. Melalui ujian korelasi pearson yang dijalankan, didapati

Nilai signifikan di antara aspek kesediaan dan aspek halangan adalah 0.341 dan ini bermaksud tidak terdapat hubungan yang signifikan di antara kedua-dua aspek tersebut. Jadual 8 menunjukkan hubungan antara kesediaan dan halangan dalam mooc.

\section{Jadual 8}

Hubungan antara tahap kesediaan dan halangan dalam penggunaan mooc

\begin{tabular}{cccc}
\hline & & Kesediaan & Halangan \\
\hline Kesediaan & Pearson correlation & 1 & -.078 \\
& Sig. (2-tailed) & & 0.341 \\
Halangan & Pearson correlation & -.078 & 1 \\
& Sig. (2-tailed) & .341 & \\
\hline \multicolumn{4}{c}{$* *$ correlation is significant at the 0.05 level (2-tailed) }
\end{tabular}

Daripada paparan hasil analisis tersebut, pekali korelasi bagi pasangan pembolehubah halanganhalangan dalam penggunaan mooc dan kesediaan menggunakan mooc adalah rendah memandangkan nilai pekali korelasi dalam lingkungan 0.01 hingga 0.30 . Ini adalah berdasarkan kepada jadual 9 yang menunjukkan anggaran kekuatan perhubungan antara dua pembolehubah.

Jadual 9

Aras kekuatan nilai pekali korelasi

\begin{tabular}{|l|l|}
\hline Saiz pekali korelasi $(\mathrm{r})$ & Kekuatan korelasi \\
\hline 0.91 hingga 1.00 atau -0.91 hingga -1.00 & Sangat kuat \\
\hline 0.71 hingga 0.90 atau -0.71 hingga -0.90 & Kuat \\
\hline 0.51 hingga 0.70 atau -0.51 hingga -0.70 & Sederhana \\
\hline 0.31 hingga 0.50 atau -0.31 hingga -0.50 & Lemah \\
\hline 0.01 hingga 0.30 atau -0.01 hingga -0.30 & Sangat lemah \\
\hline 0.00 & Tiada korelasi \\
\hline
\end{tabular}

Sumber asas statistik penyelidikan ,2014:chua yan piaw

Nilai pekali korelasi yang negatif memberitahu pengguna bahawa perkaitan atau perhubungan yang wujud antara kedua pembolehubah tersebut merupakan satu hubungan yang negatif. Contoh adalah seperti digambarkan oleh rajah 3 tentang lakaran graf mengenai hubungan nilai kolerasi yang negatif.

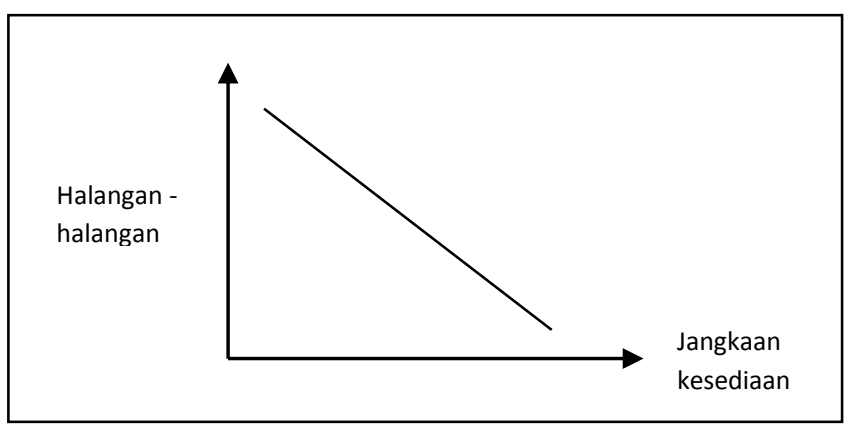

Rajah 1: Lakaran graf hubungan nilai kolerasi yang negatif

Ini menunjukkan bahawa seseorang yang memiliki jangkaan kesediaan menggunakan mooc yang tinggi akan kurang menghadapi halangan ketika menggunakan mooc dalam sesi pembelajaran dan pengajaran. 
Hasil tersebut juga jelas menunjukkan terdapatnya satu perkaitan yang signifikan di antara pembolehubah halangan-halangan dalam penggunaan mooc dan jangkaan kesediaan terhadap mooc .

\section{KESIMPULAN}

Berdasarkan analisis yang telah dibincangkan, dapat disimpulkan bahawa pensyarah wanita lebih bersedia menggunakan platform MOOC walaupun mempunyai halangan yang banyak dalam tugas harian mereka. Didapati juga, sekiranya aspek halangan tinggi ia akan menyebabkan kesediaan pensyarah rendah.

Kesediaan pensyarah PSMZA terhadap penggunaan platform MOOC secara keseluruhannya adalah dalam tahap sederhana. Ini menunjukkan bahawa kesediaan pensyarah telah berada di tahap sedia bagi memulakan dan menggunakan platform MOOC dalam pembelajaran dan pengajaran. Platform Massive Open Online Course(MOOC) dibina oleh pembangun-pembangun yang mahir dalam teknologi pendidikan. Menurut Regalado (2012), konsep MOOC yang diperkenalkan ini jelas telah mengkaji semula kaedah pembelajaran dalam talian di peringkat institusi pengajian tinggi dan berkemungkinan besar ia tidak menjadi sebuah teknologi pendidikan yang paling penting dalam jangka masa 200 tahun akan datang. Menurut David Willey (2012), MOOC boleh meluaskan akses kepada pendidikan, dan bagi mereka yang berminat ia juga dapat memperkembangkan pendidikan di institusi dan seterusnya di peringkat antarabangsa.

Kajian ini telah memberi gambaran sebenar kesediaan pensyarah Politeknik Sultan Mizan Zainal Abidin terhadap penggunaan platform MOOC sebagai bahan untuk pembelajaran dan pengajaran. Kajian ini memberi manfaat kepada Kementerian Pendidikan Tinggi, pensyarah dan seterusnya kepada pelajar itu sendiri. Hasil kajian ini diharapkan dapat menyumbang maklumat kepada pentadbir Institut Pendidikan Tinggi Awam, Pegawai Kementerian Pendidikan Tinggi tentang kesediaan pensyarah dan halangan- halangan dalam penggunaan MOOC. Maklumat ini dapat membantu pihak berkenaan dalam membuat perancangan dan strategi untuk memperlengkapkan pensyarah atau bakal pendidik dengan kemahiran-kemahiran yang perlu dalam menghadapi era globalisasi di mana platform pembelajaran di atas talian merupakan gaya pembelajaran di abad ini.

Pensyarah dapat melaksanakan tugas serta tanggungjawab mereka dengan lebih licin dan berkesan, dalam proses pembelajaran dan pengajaran dengan pembelajaran maya atau atas talian yang telah dimajukan. Hasil kajian ini juga dapat membolehkan pensyarah mengetahui tahap kesediaan diri terhadap pembelajaran atas talian yang kian pesat dibangunkan dari masa ke semasa dan halangan- halangan dalam penggunaan MOOC dalam apa jua bidang mata pelajaran. Kajian ini dapat memberi kesedaran kepada pensyarah - pensyarah di Politeknik Sultan Mizan Zainal Abidin (PSMZA) khususnya sebagai di antara pelopor dan penggerak kepada pembangunan kursus MOOC di Malaysia.

Selain itu, pengalaman pelbagai bidang ilmu dalam aplikasi MOOC ini juga akan dapat menjadi garis panduan kepada para penyelidik untuk mempelbagaikan kajian-kajian mereka pada masa akan datang. Walaubagaimanapun, kajian ini tidak dapat menggambarkan keseluruhan gaya kesediaan pensyarah dalam menggunakan platform MOOC. Setelah menjalankan kajian ini, pengkaji telah mengenalpasti beberapa cadangan kajian yang boleh dilakukan bagi tujuan penambahbaikan. Di antaranya adalah seperti kajian berkaitan perbandingan di antara penggunaan CIDOS dan MOOC di PSMZA serta kesan penggunaan Argumented Reality di dalam platform MOOC. Oleh itu, adalah diharapkan kajian-kajian seumpama ini boleh dijalankan secara lebih meluas pada masa akan datang bagi memastikan pensyarah dapat menambahbaik kaedah pengajaran dan bukan hanya mengharapkan pengajaran secara tradisional sahaja. 


\section{DAFTAR PUSTAKA}

Attan, N. \& Mohd Hamzah, M. I. (2007). Tahap Kesediaan Guru Sains Dalam Penggunaan Teknologi Maklumat Berasaskan Komputer Dalam Proses Pembelajaran dan pengajaran. Jurnal Pendidikan. 46(E): $45-60$

Bond, T. G., \& Fox, C. M.(2007). Applying the Rasch model: Fundamental measurement in the human sciences (2nd ed.). Mahwah, NJ: Lawrence Erlbaum.

Chua, Y.P., (2014). Kaedah Dan Statistik Penyelidikan Buku 2:Asas Statistik Penyelidikan Edisi Ketiga. Malaysia:Mcgraw-Hill (Malaysia) Sdn.Bhd.

Cohen L.,Manion, L.,\& Morrison,K.(2011). Research Methods In Education (7th ed., Vol, 55). New: Routledge. http://doi.org/10.1111/j.1467-8527.2007.00388_4.x

Farraj Alshehri. (2015).The Perceptions of MOOCs Learners. Journal of Emerging Trends in Computing and Information Sciences; 6(10):550-552.

Fullan, M.G.(1993). The new meaning of educational change. London: Cassell

Ghani Hj Talib.(1996). Pembinaan Instrumen: Ceramah Kursus Penyelidikan Pendidikan, Anjuran Bahagian Pendidikan Guru, Kementerian Pendidikan Malaysia, 12-13 Ogos 1996.

Cole, A. W., \& Ph, D. (2015). What Do Current College Students Think about MOOCs? Journal of Online Learning and Teaching, 11(2), 188-202.

Hudiya, A., Fariza, K., \& Aidah, A. K. (2017). Penggunaan Massive Open Online Course ( MOOC ) sebagai kaedah pembelajaran baharu. In Pembelajaran Abad ke-21: Trend Integrasi Teknologi.

Hudiya Adzhar, Fariza Khalid, A. A. K. (2015). Penggunaan Massive Open Online Course ( MOOC ) sebagai Kaedah Pembelajaran Baharu, 179-188.

Ismail, M. (2018). Amanat Ketua Pengarah Pendidikan.

Jailani, J. J. \& M. (2015). Faktor-Faktor Yang Mempengaruhi Penggunaan. Jurnal OPTIMUM (Vol. 5).

Konting, M. M.(2000). Kaedah Penyelidikan Pendidikan. Kuala Lumpur: Dewan Bahasa dan Pustaka

Mohamad Najib Abdul Ghafar (1999). Penyelidikan Pendidikan. Skudai: Penerbitan Universiti Teknologi Malaysia

Mohd Najib Abdul Ghafar. (2013). Reka Bentuk Tinjauan Soal Selidik Pendidikan. Skudai, Johor: UTM.

Mohammed Omer, Tina Klomsri, Matti Tedre, Marie Klingberg-Allvin, \& Fatumo Osman. (2015). Elearning Opens Door to the Global Community: Novice Users 'Experiences of E-learning in a Somali University. MERLOT Journal of Online Learning and Teaching, 11(2), 267-279.

Nor, M. (2012). Kesediaan Pensyarah Terhadap Perlaksanaan Pembelajaran Sepanjang Hayat Melalui Kursus Jangka Pendek Di Kolej Komuniti, 1-16.

Nor, A. (2015). Kesediaan guru dalam pendidikan integrasi science, engineering, technology and mathematics (stem).

Pelan Pembangunan Pendidikan Malaysia (Pendidikan Tinggi). (2016). Garis Panduan Pembangunan \&Penyampaian MOOC Malaysia.

Peter, K.(2007). M-learning: positioning educators for a mobile, connected future. The international review of research in open and distance learning. 8(2).

RASE, R. B. (2013). Kesediaan Pensyarah Politeknik Menggunakan Pendekatan MPembelajaran Dalam Pembelajaran dan pengajaran Di Negeri Johor.

Saijing Zheng, Mary Beth Rosson, Patrick C. Shih, dan John M. Carroll. (2015). Understanding Student Motivation, Behaviours, and Perceptions in MOOCs. CSCW '15 Proceedings of the 18th ACM Conference on Computer Supported Cooperative Work \& Social Computing. Vancouver, BC Canada:1882-1895.

Regalado, A. (2012). The most important education technology in 200 years. MIT Technology Review. www.technologyreview.com/news/506351/the-most-important-education-technology-in-200years/(1November 2016).

Robert McGuire. (2014). The Best MOOC Provider: A Review of Coursera, Udacity and Edx SkilledUp.com.http://www.skilledup.com/blog/the-best-mooc- provider-a-review-ofcourseraudacity-and edx/

Sihes, A.J. \& Bandi, E.N., (2010). Tahap Kesediaan Bakal Guru Tahun Akhir UTM (Kemahiran Hidup) Bagi Mengajar Subjek Rekacipta. Fakulti Pendidikan, Universiti Teknologi Malaysia.(Tidak Diterbitkan). Pp 1-7. 
Utusan Online. (2016). MOOC jadikan Malaysia Pusat Kecemerlangan Pendidikan Tinggi20 Februari 2016. https://www.utusan.com.my/pendidikan/kampus/mooc-jadikan-malaysiapusatkecemerlangan-pendidikan-tinggi-1.192298\#sthash.m1s4gqJr.dpuf

Wiley, D. (2012). The MOOC misnomer. Iterating toward openness. 